\title{
PERBANDINGAN HASIL BELAJAR SISWA MENGGUNAKAN MODEL PROBLEM BASED LEARNING DENGAN DISCOVERY LEARNING BERBANTU EKSPERIMEN PADA MATERI REDOKS DI SMA SWASTA ADVENT MEDAN
}

\section{COMPARISON OF STUDENT LEARNING RESULTS USING EXPERIMENTAL PROBLEM BASED LEARNING MODEL WITH DISCOVERY LEARNING IN REDOCKS MATERIALS IN MEDAN ADVENT PRIVATE VOCATIONAL SCHOOL}

\author{
Mei Retta Br Purba*, Wilda Wani Siregar, Adilah Wirdhani Lubis \\ Universitas Islam Sumatera Utara, Department of Chemistry Education, Medan 20217, \\ North Sumatera, Indonesia \\ *Corresponding author : meiretta41@gmail.com
}

\begin{abstract}
ABSTRAK
Penelitian ini bertujuan untuk mengetahui hasil belajar siswa yang menggunakan model pembelajaran Problem Based Learning berbantu ekxperiment dan model pembelajaran Discovery Learning juga berbantu eksperiment pada materi redoks di SMA Swasta Advent Medan. Sampel Penelitian ini adalah kelas X SMA kelas X-1 (eksperiment-1) menggunakan model Discovery Learning dan kelas X-2 (Eksperiment-2) menggunakan model Problem Based Learning. Hasil penelitian ini adalah hasil belajar siswa dengan model discovery learning berbantu eksperiment memiliki nilai $81,08 \%$ lebih besar dari hasil belajar kimia siswa yang mengunakan model problem based learning berbantu eksperiment sebesar $70,25 \%$. Hal ini dibuktikan melalui perhitungan uji-t dengan taraf $\alpha=0,05$ diperoleh $\mathrm{t}_{\text {hitung }}=6,29>\mathrm{t}_{\text {tabel }}=1,67$, menunjukkan bahwa $\mathrm{t}_{\text {hitung }}$ berada di luar daerah penerimaan $\mathrm{H}_{0}$, sehingga $\mathrm{H}_{0}$ ditolak dan $\mathrm{Ha}$ diterima. Dengan demikian, adanya perbandingan hasil belajar siswa yang signifikan antara kelas ekxperimen-1 dan kelas eksperimnt-2.
\end{abstract}

Kata Kunci : Problem Based Learning; Discovery Learning; Hasil Belajar; Redoks; Eksperimen.

\section{ABSTRACT}

This study aims to determine the learning outcomes of students who use ecxperimentassisted Problem Based Learning learning models and the Discovery Learning learning model is also assisted by experiments on redox material in the Medan Adventist Private High School. The sample of this study was class X SMA class X-1 (experiment-1) using the Discovery Learning model and class X2 (Experiment-2) using the Problem Based Learning model. The results of this study are student learning outcomes with experiment-assisted discovery learning models having a value of $81.08 \%$ greater than students' chemistry learning outcomes using a $70.25 \%$ problem-based learning model. This is evidenced by the calculation of the $t$-test with the level $\alpha=0.05$ obtained $t$ count $=6.29>t$ table $=1.67$, indicating that tcount is outside the reception area $\mathrm{HO}$, so $\mathrm{HO}$ is rejected and $\mathrm{Ha}$ is accepted. Thus, there is a significant comparison of student learning outcomes between ekxperimen-1 class and experimental group-2.

Keywords: Problem Based Learning, Discovery Learning; Learning Outcomes; Redox; experiment. 


\section{PENDAHULUAN}

Pendidikan merupakan proses interaksi antara guru dan siswa yang mendorong terjadinya proses belajar mengajar. Namun ada salah satu masalah yang sering ditemukan dalam proses belajar mengajar adalah siswa kurang paham atau bahkan tidak paham terhadap materi yang diajarkan oleh gurunya. Dalam belajar siswa kurang didorong dan diberinya siswa kesempatan untuk mengembangkan suatu kemampuan yang dimilikinya. Proses pembelajaran di kelas masih banyak diarahkan oleh pendidik kepada peserta didik untuk menghafal informasi Akibatnya proses belajar mengajar tidak bermanfaat bagi siswa.

Proses pembelajaran yang berpusat pada guru akan mempengaruhi keaktifan siswa. Berdasarkan jurnal olah Riski Resa dkk, meneliti adanya peningkatan skor hasil belajar siswa dari siklus I sebesar 72,76 (cukup) menjadi 83,70 (baik) dengan metode belajar inkuiri. Membuktikan Model Pembelajaran mendorong aktifitas siswa bukan pada guru saja. (Riski resa, dkk.2017)

Dalam belajar, siswa juga harus aktif mengolah bahan, mencerna, memikirkan, menganalisis, sampai akhirnya siswa tersebut dapat merangkum materi sebagai pengertian yang utuh. Karena itu model pembelajaran yang beragam akan membantu keaktifan tersebut. Dalam penelitian dengan model pembelajaran berbasis pemasalahan kelas eksperiment memiliki peningkatan hasil belajar 87,5 sedang kelas control dengan rerata hasil belajar 77,3. (Bunga Amelia, dkk. 2015)

Berdasarkan pengalaman mengajar pada saat PPLT di SMA, di kelas aktivitas siswa dalam belajar kimia sangat rendah, sehingga siswa cenderung pasif dalam belajar. Hal tersebut tentu akan berpengaruh terhadap hasil belajar. Guru peminatan kimia kelas X juga masih menggunakan metode konvensional dalam kegiatan belajar-mengajar sehingga pembelajaran masih berpusat pada guru yang dapat mengakibatkan aktivitas siswa dan prestasi belajar siswa menjadi rendah karena siswa cenderung pasif. Hal ini ditunjukkan dengan rata-rata nilai ulangan akhir semester kimia kelas X SMA sebesar 65 sedangkan standar KKM nilai sebesar 70. Hasil pengamatan pada hasil belajar siswa, selama proses pembelajaran berlangsung nampak bahwa sekitar $40 \%$ siswa kelas X yang mendapat nilai 70. Hal ini disebabkan pembelajaran di kelas masih didominasi oleh guru, belum menekankan pada kegiatan aktif siswa (student centered) dalam membangun konsep.

Berdasarkan permasalahan tersebut, sudah banyak model pembelajaran yang digunakan agar siswa aktif dalam proses pembelajaran. Berdasarkan Permendikbud Nomor 65 Tahun 2013 tentang Standar Proses, model pembelajaran yang diutamakan dalam implementasi Kurikulum 2013 adalah model, model pembelajaran penemuan (Discovery Learning) yaitu Teknik penemuan atau discovery menurut Roestiyah (2008: 20) adalah proses mental dimana siswa mampu mengasimilasikan sesuatu konsep atau prinsip. Yang dimaksudkan dengan proses mental tersebut antara lain ialah: mengamati, mencerna, mengerti, menggolong-golongkan, membuat dugaan, menjelaskan, mengukur, membuat kesimpulan dan sebagainya. Suatu konsep misalnya: segitiga, panas, demokrasi dan sebagainya, sedang yang dimaksud dengan prinsip antara lain ialah: logam apabila dipanaskan akan mengembang. Dalam teknik ini siswa dibiarkan menemukan sendiri atau mengalami proses mental itu sendiri, guru hanya membimbing dan memberikan instruksi.

Pembelajaran discovery menurut Hanafiah dan Suhana (2012: 77) merupakan suatu rangkaian kegiatan pembelajaran yang melibatkan secara maksimal seluruh kemampuan peserta didik untuk mencari dan menyelidiki secara sistematis, kritis, dan logis sehingga mereka dapat menemukan sendiri pengetahuan, sikap dan keterampilan sebagai wujud adanya perubahan perilaku, model pembelajaran berbasis permasalahan (Problem Based Learning). Yaitu suatu pembelajaran yang menekankan pada pemberian masalah nyata dalam kehidupan sehari-hari yang harus dipecahkan oleh siswa melalui investigasi mandiri untuk mengasah kemampuan berpikir kreatif dalam pemecahan masalah agar terbentuk solusi dari permasalahan tersebut sebagai pengetahuan dan konsep yang esensial dari pembelajaran. (Rizal Abdurrozak, dkk. 2016). Dengan demikian, PBL mempunyai keunggulan dalam mengembangkan kekayaan pengalaman belajar melalui proses kognitif yang kritis yang diintegrasikan dengan pengetahuan yang telah dimiliki, dan mengembangkan kemampuan untuk menerapkan yang diasosiasikan pada situasi berbeda dan masa yang akan datang (Susetyo, 2004) selain daripada itu ad juga model pembelajaran inkuiri (Inquiry Based Learning), model pembelajaran berbasis proyek (Project Based Learning) dan lain sebagainya.

Karakteristik model pembelajaran berbasis permasalahan (Problem Based Learning). ini cocok jika diterapkan pada konsep/materi yang memungkinkan siswa aktif untuk menganalisis dan 
memecahkan persoalan secara sistematis. Dan Konsep Karakteristik model pembelajaran penemuan (Discovery Learning) ini sesuai saat diterapkan pada konsep/materi yang memungkinkan siswa aktif untuk memecahkan dan menemukan persoalan secara sistematis yang sesuai dengan karakteristik model pembelajaran discovery learning salah satunya adalah pada konsep reaksi reduksi dan oksidasi. Observasi melalui beberapa jurnal yng telah diterbitkan banyak mengunakan model pembelajaran penemuan (Discovery Learning) dan pembelajaran berbasis permasalahan (Problem Based Learning).

Berdasarkan permasalahan di atas, maka peneliti ingin meneliti mengenai membandingkan model pembelajaran penemuan (Discovery Learning) dan pembelajaran berbasis permasalahan (Problem Based Learning) tersebut untuk mengetahui berapa besar pengaruh pembelajaran dan untuk mengetahui bagaimana hasil belajar siswa pada pokok bahasan reaksi redoks dengan membandingkan model Problem based learning dan model Discoveri learning ini dnegan berbantu eksperiment.

Tujuan dalam penelitian ini adalah :Untuk mengetahui apakah hasil belajar siswa yang menggunakan model pembelajaran Problem Based Learning dan model pembelajaran Discovery Learning pada materi redoks. Dan untuk mengetahui adanya perbedaan signifikan terhadap hasil belajar siswa yang menggunakan model pembelajaran Problem Based Learning dengan model pembelajaran Discovery Learning pada materi redoks. Reaksi redoks banyak terdapat dalam kehidupan sehari hari diantaranya pembakaran, metabolisme, dan perkaratan. Konsep reaksi redoks mengalami perkembangan.. Reaksi reduksi dan oksidasi selalu berlangsung pada saat yang sama, karena itu disingkat sebagai reaksi redoks.

Salah satu manfaat yang paling penting dari bilangan oksidasi dalam menyeimbangkan persamaan redoks. Persamaan ini dapat menjadi sangat rumit, dan metode sistematik untuk menyeimbangkan menjadi penting. Terdapat dua metode berbeda untuk menyeimbangka reaksi redoks, yaitu metode perubahan bilangan oksidasi dan metode ion-elektron.(David E, 2008 : 164)

Reaksi oksidasi-reduksi berperan dalam banyak hal di dalam kehidupan kira sehari -hari. Reaksi ini terlibat mulai pembakaran bahan bakar minyak bumi sampai degan kerja cairan pemutih yang digunkan dalam rumah tangga. Selain itu, sebagian besar unsur logam dan non logam diperoleh dari bijihnya melalui proses oksidasi atau reduksi.

\subsection{Jenis Penelitian}

\section{METODE PENELITIAN}

Penelitian ini melibatkan dua kelas yang berbeda. Satu kelas dijadikan sebagai kelas eksperimen1 dan kelas lainnya dijadikan sebagai kelas eksperimen-2. Untuk mengetahui kompetensi siswa, siswa diberikan tes pretes dan postes oleh guru pelajaran pada kedua kelas tersebut. Desain penelitian ini dapat dilihat pada tabel berikut ini :

Tabel 1. Two Group Pretest - Posttest Design

\begin{tabular}{cccc}
\hline Kelas & Pretes & $\begin{array}{c}\text { Perlakuan oleh } \\
\text { guru }\end{array}$ & Postes \\
\hline Eksperimen-1 & $\mathrm{T}_{1}$ & $\mathrm{X}_{1}$ & $\mathrm{~T}_{2}$ \\
\hline Eksperimen-2 & $\mathrm{T}_{1}$ & $\mathrm{X}_{2}$ & $\mathrm{~T}_{2}$ \\
\hline
\end{tabular}

Keterangan :

$\mathrm{X}_{1}=$ Pembelajaran dengan menggunakan model pembelajaran berdasarkan masalah (PBL) pada materi redoks

$\mathrm{X}_{2}=$ Pembelajaran dengan menggunakan model pembelajaran Discory Learning pada materi redoks

$\mathrm{T}_{1}=$ Pretes diberikan kepada kelas eksperimen-1 dan kelas eksperimen-2 sebelum perlakuan

$\mathrm{T}_{2}=$ Postes diberikan setelah perlakuan pada kelas eksperimen-1 dan kelas eksperimen-2 


\subsection{Waktu dan Tempat Penelitian}

Penelitian ini dilakukan pada bulan Mei semester genap di SMA Swasta Advent Air Bersih Medan.

\subsection{Target/Subjek Penelitian}

Populasi dalam penelitian ini adalah seluruh siswa kelas X semester genap SMA Swasta Advent Medan yang terdiri dari 2 kelas yaitu kelas X-1 dan kelas X-2 dan masing-masing kelas terdiri dari 30 orang. Jadi, jumlah seluruh siswanya adalah 60 orang. Sampel dalam penelitian ini adalah semua populasi siswa yaitu kelas X-1 sebagai kelas eksperimen-1 dan kelas X-2 sebagai kelas eksperimen-2.

\subsection{Prosedur}

Adapun tahapan-tahapan prosedur penelitian dibagi dalam beberapa langkah, diantaranya yaitu :

1. Tahap Awal (Persiapan dan Perencanaan)

a. Melakukan konsultasi dengan Dosen Pembimbing

b. Melakukan observasi atau studi pendahuluan

c. Melakukan wawancara dengan guru kimia tentang masalah-masalah yang dihadapi siswa dalam pembelajaran kimia

d. Menyiapkan instrumen pengumpul data yang akan digunakan dalam penelitian.

2. Tahap Pelaksanaan Penelitian

a. Melakukan pendataan siswa-siswa pada kelas eksperimen-1 dan kelas eksperimen-2

b. Melaksanakan tes kemampuan awal (pretes) pada kelas eksperimen-1 dan kelas eksperimen-2 untuk mengetahui kompetensi, kenormalan dan homogenitas siswa sebelum diberi perlakuan

c. Memberikan perlakuan pada proses pembelajaran dengan menggunakan pembelajaran Discovery Learning berbantu eksperimen-1 pada kelas eksperimen-2 dan pemberian perlakuan dengan menggunakan pembelajaran PBL pada kelas eksperimen

d. Memberikan postes pada kedua kelas dengan soal yang sama untuk mengetahui hasil belajar siswa setelah diberikan perlakuan.

3. Tahap Akhir Penelitian (Pengumpul dan Pengolahan Data)

Setelah seluruh perlakuan dalam penelitian ini selesai maka seluruh data tersebut dapat dikumpulkan dan kemudian dilakukan pengolahan data :

a. Data skor/nilai pretes dan postes stiap siswa ditabulasi. Selanjutnya menghitung selisih nilai hasil belajar yang diperoleh di kelas eksperimen-1 dan eksperimen-2 tersebut sebelum dan sesudah perlakuaan.

b. Uji Normalitas data.

c. Uji Homogenitas data.

d. Menghitung rata - rata (mean) Perubahan (peningkatan/penurunan) nilai hasil belajar yang diperoleh di setiap kelas.

e. Membandingkan perubahan/ peningkatan atau penurunan nilai yang diperoleh dikelas eksperimen-1 dan kelas eksperimen-2

f. Menerapkan uji statistic yang cocok untuk menguji apakah peningkatan hasil belajar siswa di kelas eksperimen-1 lebih baik dari kelas eksperimen-2

g. Menarik kesimpulan penelitian.

\subsection{Teknik Pengumpulan Data}

Data diambil dan dikumpulkan dari hasil belajar siswa yang diambil dengan memberikan tes kepada siswa yaitu sebelum melakukan kegiatan pembelajaran, dilaksanakan pretes untuk mengetahui tingkat kemampuan siswa pada materi pokok redoks pada kelas eksperimen dan eksperimen. Pembelajaran di kelas dapat dilaksanakan setelah pretes dilakukan. Setelah melaksanakan 
pembelajaran pada materi redoks maka dilakukan postes untuk mengetahui kompetensi hasil siswa pada kelas eksperimen dan eksperimen. Setelah terkumpul maka di lakukan : pengujian validitas tes yang merupakan suatu ukuran untuk mengetahui tingkat dari kevalidan atau keabsahan instrumen.

\subsection{Teknik Analisis Data}

Untuk analisis data dalam penelitian ini menggunakan : (1) uji normalitas data yang dilakukan adalah untuk mengetahu apakah sampel uang digunakan didistribusi normal atau tidak. Untuk menguji normalitas data dapat digunkan rumus Lilierfors(Sudjana,1989); (2) uji homogenitas ini dilakukan untuk mengetahui apakah data nilai post-test homogen atau tidak; (3) untuk hipotesis digunakan rumus uji-t( puhak kanan) $\mathrm{n} 1 \neq \mathrm{n} 2$ (Sudjana, 2005); (4) uji peningkatan hasil belajar.

\subsection{Analisis Data}

\section{HASIL DAN PEMBAHASAN}

Berdasarkan hasil perhitungan diperoleh data statistik hasil belajar siswa pada kelas eksperimen-1 dan kelas eksperimen-2 yang dirangkum dalam tabel statistik deskriptif hasil belajar siswa kelas eksperimen-1 dan kelas eksperimen-2 pada Tabel 2.

Tabel 2. Data Statistik Kelas Eksperimen

\begin{tabular}{cccc}
\hline \multirow{2}{*}{ Data } & \multirow{2}{*}{ Statistik } & \multicolumn{2}{c}{ Kelas } \\
\cline { 3 - 4 } & Rata rata & Eksperimen-1 & Eksperimen-2 \\
\hline Pretest & Nilai minimum & 47,39 & 46,00 \\
\hline & Nilai maksimal & 66,67 & 23,33 \\
\hline Nilai Total & 1421,67 & 66,67 \\
\hline Posttest & Rata rata & 81,08 & 1380 \\
\hline & Nilai minimum & 65,00 & 70,25 \\
\hline & Nilai maksimal & 90,00 & 47,50 \\
\hline Nilai Total & 2432,50 & 92,50 \\
\hline
\end{tabular}

\subsubsection{Uji Normalitas}

Hasil perhitungan untuk uji normalitas data hasil belajar siswa kelas eksperimen-1 dan kelas eksperimen-2 (Pretes dan Postes) dengan menggunakan uji Chi - Kuadrat pada taraf nyata $a=0,05$ dengan kriteria Chi Kuadrat $\mathrm{X}^{2}$ hitung $=\mathrm{X}^{2}$ Tabel maka dapat dinyatakan berdistribusi normal dapat dilihat pada tabel 3 berikut:

Tabel 3. Uji Normalitas Data Hasil Belajar Siswa

\begin{tabular}{cccccc}
\hline \multirow{2}{*}{ Kelas } & $\begin{array}{c}\text { Sumber } \\
\text { Data }\end{array}$ & $\mathbf{X}^{2}$ Hitung & $\mathbf{X}^{2}$ tabel & $\boldsymbol{\alpha}$ & Keterangan \\
\hline \multirow{2}{*}{ Eksperimen-1 } & Pretest & 8,66 & 11,07 & 0,05 & Distibusi Normal \\
\cline { 2 - 6 } Eksperimen-2 & Postest & 8,1 & 11,07 & 0,05 & Distibusi Normal \\
\cline { 2 - 6 } & Pretest & 5,61 & 11,07 & 0,05 & Distibusi Normal \\
\hline
\end{tabular}

Berdasarkan tabel 3 disimpulkan bahwa :

1. Uji normalitas data hasil belajar siswa kelas eksperimen-1 terlihat harga Chi Kuadrat ( $\mathrm{X}^{2}$ hitung $)$ $<$ harga chi Kuadrat $\left(\mathrm{X}^{2}\right.$ Tabel $)$ maka dapat disimpulkan data hasil belajar kimia siswa berdistribusi normal. 
2. Uji normalitas data hasil belajar siswa kelas eksperiment-2 terlihat harga Chi Kuadrat $\left(\mathrm{X}^{2}{ }_{\text {hitung }}\right)$ $<$ harga chi Kuadrat $\left(\mathrm{X}^{2}\right.$ Tabel $)$ maka dapat disimpulkan data hasil belajar kimia siswa berdistribusi normal.

\subsubsection{Uji Homogenitas}

Hasil perhitungan untuk uji normalitas data hasil belajar siswa kelas eksperimen-1 dan kelas eksperimen-2 (Pretest dan posstest) dengan menggunakan uji Chi -Kuadrat pada taraf nyata $a=0,05$ dengan criteria Chi Kuadrat $\mathrm{X}^{2}$ hitung $=\mathrm{X}^{2}$ Tabel maka dapat dinyatakan berdistribusi normal dapat dilihat pada tabel 4 berikut:

Tabel 4. Uji Homogenitas Data Hasil Belajar Siswa

\begin{tabular}{|c|c|c|c|c|c|}
\hline $\begin{array}{c}\text { Sumber } \\
\text { Data }\end{array}$ & Kelas & $\mathbf{S}^{2}$ & $\mathbf{F}_{\text {hitung }}$ & $\mathbf{F}_{\text {tabel }}$ & Keterangan \\
\hline \multirow{2}{*}{ Pretest } & Eksperimen-1 & 71,42 & \multirow{2}{*}{1,57} & \multirow{2}{*}{1,76} & \multirow{2}{*}{ Homogen } \\
\hline & Eksperimen-2 & 45,22 & & & \\
\hline \multirow{2}{*}{ Postest } & Eksperimen-1 & 51,1 & \multirow{2}{*}{0,91} & \multirow{2}{*}{1,76} & \multirow{2}{*}{ Homogen } \\
\hline & Eksperimen-2 & 55,9 & & & \\
\hline
\end{tabular}

\subsubsection{Uji Hipotesis}

Setelah diketahui bahwa data hasil belajar siswa terdistribusi normal dan homogen maka dapat dilakukan uji hipotesis dengan menggunakan uji statistik satu pihak yaitu uji t pihak kanan. Uji ini untuk mengetahui apakah hipotesis dalam penelitian ini diterima atau ditolak. Ktiteria pengujian jika $t_{\text {hitung }}>t_{\text {tabel }}$ maka hipotesis akternatif diterima dan hipotesis nihil atau hipotesis ditolak. Data hasil uji hipotesis dapat dilihat pada tabel 5 sebagai berikut ini:

Tabel 5. Uji Hipotesis Data Hasil Belajar Siswa

\begin{tabular}{ccccc}
\hline \multicolumn{2}{c}{ Data Gain Kelas } & \multirow{2}{*}{$\mathbf{t}_{\text {hitung }}$} & \multirow{2}{*}{$\mathbf{t}_{\text {tabel }}$} & \multirow{2}{*}{ Keterangan } \\
\cline { 1 - 2 } Eksperimen-1 & Eksperimen-2 & & & \\
\cline { 1 - 2 } $\mathrm{X}=81,08$ & $\mathrm{X}=70,25$ & 6,29 & 1,67 & \multirow{2}{*}{ Ha diterima } \\
\hline $\mathrm{S}^{2}=51,15$ & $\mathrm{~S}^{2}=55,97$ & & & \\
\hline
\end{tabular}

Dari hasil perhitungan data tabel 5 diatas diperoleh nilai $t_{\text {hitung }}$ lebih besar daripada $t_{\text {tabel }}$ maka Ho ditolak yang artinya Ha diterima sehingga dapat disimpulkan bahwa peningkatan hasil belajar siswa yang diajarkan menggunakan model discovery learning lebih tinggi dari pada hasil belajar siswa yang diajarkan dengan menggunakan model problem based learning berbantu eksperimen.

Berdasarkan analisa uji-t satu pihak (pihak kanan) diperoleh $t_{\text {hitung }}>t_{\text {tabel }}$ pada $a=0,05$ yang artinya Ho ditolak dan Ha diterima. sehingga dapat disimpulkan bahwa peningkatan hasil belajar siswa yang diajarkan menggunakan model discovery learning lebih tinggi dari pada hasil belajar siswa yang diajarkan dengan menggunakan model problem based learning berbantu eksperimen.

\subsection{Pembahasan}

Penelitian ini merupakan jenis penelitian eksperiment pada bidang pendidikan. Penelitian ini dilaksanakan di SMA Swasta Advent Medan. Sampel siswa yang digunakan adalah dua kelas. Dimana kelas X-1 dijadikan sebagai kelas eksperimen-1 yang dibelajarkan dengan Discovery Learning berbantu eksperimen sedangkan kelas kedua yaitu X-2 diajdikan eksperimen-2 yang dibelajarkan dengan menggunakan model Problem Based Learning berbantu eksperimen. Tinjauan yang digunakan sebagai variabel terikat adalah hasil belajar siswa. Hipotesis yang digunakan dalam penelitian ini meliputi manakah yang lebih tinggi antara hasil belajar siswa yang dibelajarkan dengan menggunakan 
model discovery learning berbantu eksperimen dibandingkan dengan hasil belajar siswa yang dibelajarkan dengan menggunakan model problem based learning berbantu eksperimen pada mata pelajaran kimia materi redoks.

Hipotesis diajukan kemudian diuji statistik berdasarkan data hasil penelitian yang telah diperoleh. Sebelum dilakukan uji hipotesis dilakukan terlebih dahulu uji prasyarat analisis yaitu uji normalitas dan uji homogenitas, dimana yang duji prasyarat adalah nilai pretes, postes dan hasil belajar. Dari uji normalitas data terdistribusi normal dan dari uji homogenitas data bersifat homogen. Setelah kedua uji tersebut terpenuhi selanjutnya uji hipotesis yakni uji satu pihak (pihak kanan) yakni untuk melihat hasil belajar siswa (hipotesis pertama)

Hasil belajar siswa yang diajarkan dengan menggunakan model pembelajaran discovery learning berbantu eksperimen dan kelas yang menggunakan model Problem based learning berbantu eksprimen diukur dari rata - rata hasil belajarnya yaitu 81,08 pada kelas eksperimen-1 dan 70,25 pada kelas eksperimen-2. Hal ini berarti, Ha diterima dan Ho ditolak yang menyatakan "belajar siswa yang dibelajarkan dengan menggunakan model pembelajaran discovery learning berbantu eksperimen lebih baik dari hasil belajar siswa menggunakan model problem based learning pembelajaran materi kimia redoks"

Hasil penelitian ini mengalami kenaikan hasil belajar, pada kelas eksperimen-1, grafik 1 setelah dibelajarkan dengan model pembelajaran didapati 3 orang mengalami kenaikan dibawah 10\%, 2 orang mengalami kenaikan dibawah 20\%, 20 orang mengalami kenaikan 30-50\%, dan 4 orang naik diatas $50 \%$. Sehingga 5 orang yang dibawah $20 \%$ itu adalah natan 3,3\%, Hary $16,7 \%$, Gary $8,33 \%$, jane $5,83 \%$ dan emma $10 \%$. Hal ini disebabkan karena mereka pada saat diberi perlakuan akan model pembelajaran kimia materi redoks kurang mengemari dan minat kurang akan permbelajaran ini. Sedang siswa yang mengalami peningkatan diatas $50 \%$ memiliki semangat dan minat dalam mempelajari kimia materi redoks. Adapun persen kenaikan nilai yaitu 33,36\%.

Pada kelas eksperimen-2, grafik 2 setelah diberlajarkan dengan model pembelajaran Problem basic learning terdapat hal sebagai berikut, 3 orang mengalami penurunan hasil belajar, 4 orang naik sekitar $10 \%, 4$ orang naik diatas $20 \%, 18$ orang mengalami kenaikan $30-50 \%$ dan 7 orang mengalami kenaikan diatas 50\%. Adapun siswa yang mengalami penurunan yaitu Aldre 1,67\%, Philip 12,50\%, dan agung $11,67 \%$. Sedangkan siswa yang mengalami kenaikan $10 \%$ yaitu Frengklin, aurora, katri dan rikky. Siswa yang mengalami penurunan karena kurang mampu dalam mengadopsikan mareti redok sehingga terjadi penurunan dan kenaikan yang sangat mencolok. Adapun persen kenaikan nilai yaitu $24,25 \%$

Pada pelaksanaannya, pembelajran menggunakan model discovery learning menuntut siswa untuk menyadari bahwa banyak hal di lingukungn di sekitar yang perlu untuk dianalisis penyebabnya, khususnya yang berhubungan dengan pelajaran kimia materi redoks, sehingga menuntut siswa untuk berpikir tingkat tinggi untuk menganalisis masalah yang diberikan dalam proses penemuan.

Model pembelajara problem based learning dan discovery learning berbantu eksperiment dapat meningkatkan hasil belajar kimia siswa pada materi reaksi oksidasi dan reduksi merupakan pembelajaran yang berpusat pada siswa.

Berdasarkan hal tersebut, maka hasil belajar siswa pada materi reaksi oksidasi reduksi (redoks) dapat dimaksimalkan dengan menggunakan model pembelajaran problem based learning dan discovery learning berbantu eksperiment dimana model DL sebesar 81,08 \% sedangkan PBL sebebsar $70,25 \%$ dikarenakan model discovery learning merupakan model pembelajran yang inovatif yang dapat memberikan kondisi belajar aktif kepada siswa dimana guru memberikan masalah kepada siswa dan dipecahkan siswa sendiri masalah dalam pembelajaran dan mereka sendiri yang memecahkan masalah tersebut. 


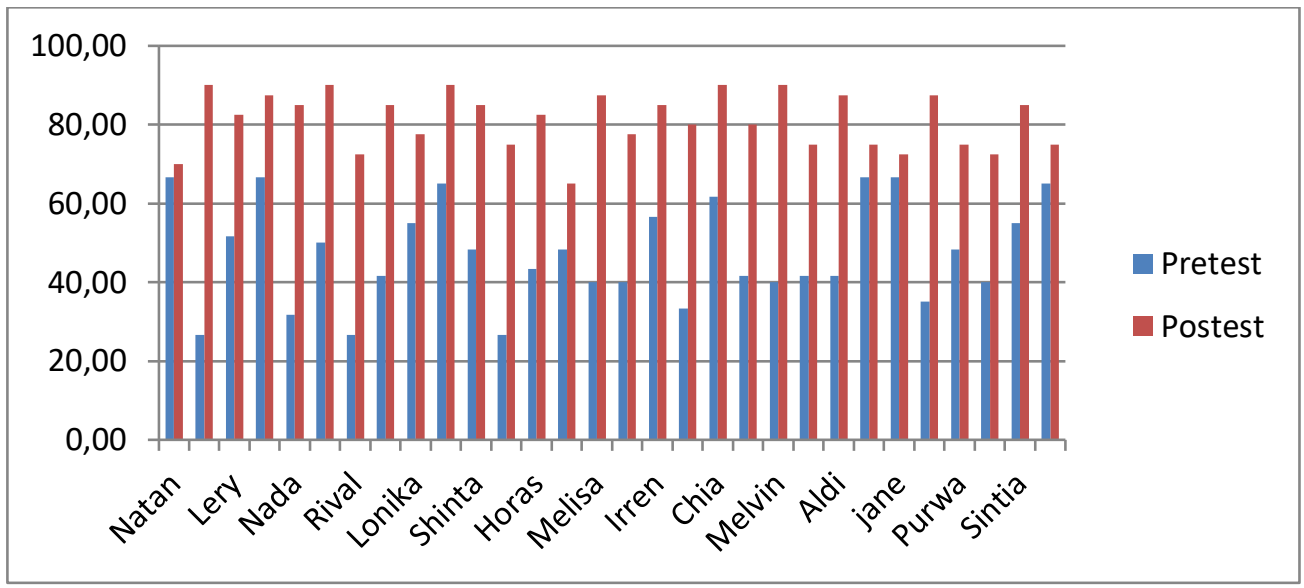

Grafik 1. Perbandingan Nilai Pretes dan Postes Kelas Eksperimen-1

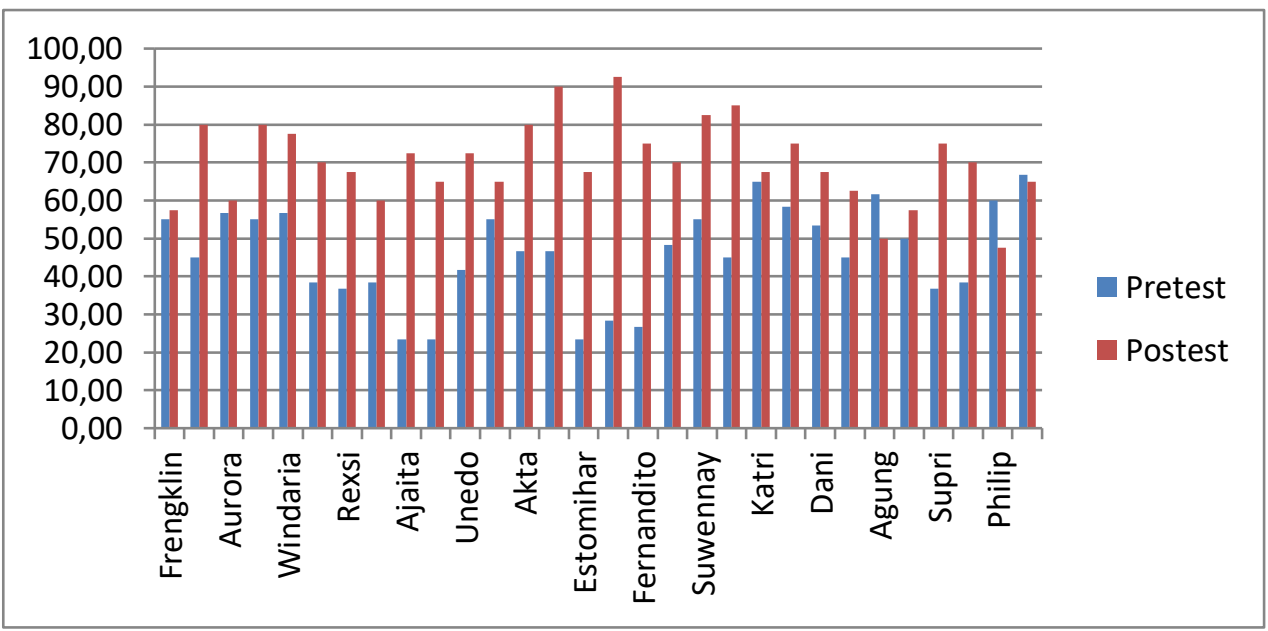

Grafik 2. Perbandingan Nilai Pretes dan Postes Kelas Eksperimen-2

\section{SIMPULAN DAN SARAN}

\subsection{Simpulan}

Berdasarkan hasil penelitian yang telah dilakuakn maka dapat diambil kesimpulan yaitu :

1. Hasil belajar kimia siswa yang dibelajarkan dengan menggunakan model discovery learning berbantu eksperiment memiliki nilai $81,08 \%$ lebih besar dari hasil belajar kimia siswa yang mengunakan model problem based learning bebantu eksperiment sebesar 70,25\%.

2. Kelas eksperimen-1 berdasarkaan grafik terdapat 3 orang mengalami kenaikan dibawah $10 \%, 2$ orang mengalami kenaikan dibawah 20\%, 20 orang mengalami kenaikan 30-50\%, dan 4 orang naik diatas $50 \%$. Sehingga 5 orang yang dibawah $20 \%$ itu adalah natan 3,3\%, Hary $16,7 \%$, Gary $8,33 \%$, jane $5,83 \%$ dan emma $10 \%$. Pada kelas eksperiment 2,3 orang mengalami penurunan hasil belajar, 4 orang naik sekitar $10 \%, 4$ orang naik diatas $20 \%, 18$ orang mengalami kenaikan $30-50 \%$ dan 7 orang mengalami kenaikan diatas $50 \%$.

3. Adapun persen kenaikan nilai pada kelas eksperiment-1 yaitu 33,36\% dan kelas eksperimen-2 yaitu $24,25 \%$. 


\subsection{Saran}

Berdasarkan pembahasan dan kesimpulan yang telah dikemukakan di atas maka penulis menyarankan hal - hal berikut.

1. Bagi guru dan calon guru dapat menerapkan model discovery leraning berbantu eksperiment sehingga mempermudah pencapaian tujuan instruksional dan dapat meningkatkan hasil belajar siswa, khususnya pada mata pelajaran kimia materi redoks.

2. Mahasiswa yang berminat dengan materi redoks dapat mengadakan penelitian lanjutan tentang model pembelajaran problem based learning dan discovery leraning dan diharapkan dengan menggunakan dua kelas dengan sekolah yang berbeda sebagai studi pembanding dan untuk mendapatkan hasil yang lebih baik dan perbedaaan hasil belajar yang lebih signifikan dan juga dengan media atau eksperiment berbeda.

3. Untuk kesempurnaan penelitian ini, disarankan mengadakan penelitian lanjutan dengan melibatkan variabel - variabel efektif lainnya, seperti gaya belajar, inteligentasia, kierja ilmiah, maupun variabel - variabel lainnya.

4. Bagi penulis selanjutnya yang ingin meneliti lebih lanjut mengenai model pembelajaran problem based learning dan discovery learning berbantu eksperiment, sebaiknya memperhatikan kelemahan - kelemahan dalam menerapkan model dan media dalam pembelajaran in agar diperoleh hasil yang lebih baik.

\section{DAFTAR PUSTAKA}

Bunga Amelia, dkk. 2015. Pemanfaatan Model Pltl Berbantuan Lks Berbasis Inkuiri Untuk Meningkatkan Kompetensi Kimia. Jurnal Inovasi Pendidikan Kimia, FMIPA Universitas Negeri Semarang. (Volume 9, Nomor 1) hlm 1496 -1505

E. Goldberg, David.2008. Kimia untuk Pemula. Edisi Ketiga. Jakarta : Erlangga

Hanafiah dan Suhana. (2012). Konsep StrategiPembelajaran. Bandung: PT RefikaAditama.

Nana Sudjana. 2014. Penelitian Hasil Proses Belajar Mengajar. Bandung: Remaja Rosdakarya.

Risky Resa, dkk. 2017. Meningkatkan Aktivitas Dan Hasil Belajar Siswa Dengan Model Pembelajaran Inkuiri Terbimbing Pada Materi Redoks. QUANTUM, Jurnal Inovasi Pendidikan Sains. (Volume 8, Nomor 1): 43-51

Roestiyah. 2008. Strategi Belajar Mengajar. Jakarta: Rineka Cipta

Seftin, Dwi.2012. Meningkatkan Hasil Belajar Siswa Pada Konsep Reaksi Reduksi Oksidasi Melalui Pembelajaran Kooperatif Model Team Games Tournament (Tgt) Berbantuan Media Pembelajaran Ular Tangga Redoks Di Kelas X 2 Sma Negeri 1 Tanjung. Jurnal Inovasi Pendidikan Sains, (Vol.3, No.2) Ouantum.

Sri Anitah, dkk. 2009. Strategi Pembelajaran. Jakarta. Universitas Terbuka

Sri Wardani, dkk.2016,Pengaruh Pembelajaran Inkuiri Terbimbing Terhadap Pemahaman Konsep Dan Oral Activities Pada Materi Pokok Reaksi Reduksi Dan Oksidasi. Jurnal Inovasi Pendidikan Kimia, FMIPA Universitas Negeri Semarang. Jurnal Inovasi Pendidikan Kimia, (Volume 10, Nomor 2) halaman 1743 - 1750

Sudijono,Anas.2011. Pengantar evaluasi Pendidikan. Jakarta : PT Rajagrafindo Persada

Sudjana. 2002. Metode Statistika.Bandung: Tarsito. 